\title{
The $\sqrt{\text { JoURNAL of }}$
OUR ECONOMIC HISTORY
}

Papers Presented at the Fifty-First Annual MeEting of the ECONOMic History Association

CARR (Presidential Address), Emigration and the Standard of Living hoffman, Postel-vinay, and rosenthal, Private Credit Markets in Paris, $1690-1840$

DE LONG, Productivity Growth and Machinery Investment MOKYR, Technological Inertia in Economic History Brown, Market Organization, Protection, and Vertical Integration ESPOSTO, Italian Industrialization and the Gerschenkronian "Great Spurt" GRUBB, Educational Choice in the Era Before Free Public Schooling $\mathrm{COHN}$, The Occupations of English Immigrants to the U.S., 1836-1853 PHILlips, Patent Growth in the Old Dominion FIELD, The Magnetic Telegraph and the New Management of Capital SUnDSTRom, Unemployment and Urban Black Workers during the Great Depression

KOSSOUdJ AND DRESSER, Women Industrial Workers during World War II DISSERTATION SUMMARIES 


\title{
THE JOURNAL OF ECONOMIC HISTORY \\ ISSN 0022-0507
}

Published for the Economic History Association in cooperation with The University of Kansas by Cambridge University Press

\author{
EDITORS \\ Thomas Weiss Peter lindert \\ EDITORIAL STAFF \\ Brian Black and Pamela Evans, Assistant Edrors \\ Joshua RoSENBloOM, EDITORIAL ASSISTANT \\ William H. BeCKer, AsSociation BusinesS MANaGER
}

EDITORIAL BOARD

\author{
Jeremy Atack, Illinois \\ Michael Bernstein, California, San Diego \\ George R. Boyer, Cornell \\ Judith C. Brown, Stanford \\ Louis P. Cain, Loyola \\ Ann Carlos, Colorado, Boulder \\ Jon S. Cohen, Toronto \\ Bernard Elbaum, California, Santa Cruz \\ Price Fishback, Arizona \\ David Good, Minnesota
}

\author{
Farley Grubb, Delaware \\ Timothy Hatton, Essex \\ Carol Heim, Massachusetts, Amherst \\ Philip T. Hoffman, California Institute of Technology \\ Angela Redish, British Columbia \\ Gary Saxonhouse, Michigan \\ Richard H. Steckel, Ohio State \\ John Wallis, Maryland \\ Eugene N. White, Rutgers \\ Mary Yeager, California, Los Angeles
}

Aims and Scope: The Journal of Economic History seeks to promote the scholarly study of economic aspects of the human past from a diversity of perspectives, notably those of economists and historians. By encouraging careful formulation of issues and clear exposition of methods, the JourNal hopes to stimulate discourse among scholars with varied interests and modes of inquiry.

The Journal is abstracted in The Journal of Economic Literature, which is part of the DIALOG on-line data service.

Instructions for Contributors: Articles on economic history and related aspects of history or economics will be considered for publication by the Editors on the understanding that the articles have not previously been published and are not under consideration elsewhere. Papers should indicate the wider significance of detailed original research findings as well as the logic and limitations of specialized techniques of analysis. Comments and shorter notes are also welcome. The Journal does not accept unsolicited book reviews, nor can it honor requests to review particular works. Contributions should be typed double-spaced. Footnotes, also double-spaced, should be grouped at the end of the paper, along with figures and tables. Four copies of each manuscript should be submitted. Prospective contributors may obtain a copy of the Style Sheet for the JourNal from the Editorial Office. A submission fee of $\$ 20.00$ or a year's membership (fee schedule below) is required from nonmembers of the Association.

Editorial Office Address: The Editors, The Journal of Economic History, Agricultural History Center, University of California, Davis, CA 95616-8513, U.S.A. Telephone: (916) 752-5608.

Association Office Address and Membership Information: Individuals who are members of the Economic History Association receive the Journal as part of their annual dues. Membership rates (in U.S. dollars) are $\$ 30.00$ for those with income above $\$ 30,000$ a year; $\$ 25.00$ for those with income below $\$ 30,000$; $\$ 15.00$ for students and for professors emeriti who have been members of the Association for 10 years; $\$ 600.00$ for life membership. Payment of an additional $\$ 20.00$ permits joint membership with the Economic History Society (UK). Applications and inquiries concerning membership should be addressed to the Economic History Association, Dept. of History, George Washington University, Washington, DC 20052, U.S.A.

Subscription, Publishing, and Advertising Office Address: Cambridge University Press, 40 West 20th Street, New York, NY 10011-4211, U.S.A.; or Cambridge University Press, The Edinburgh Building, Shaftesbury Road, Cambridge CB2 2RU, England.

Subscription Information: The Journal of Economic History is published quarterly in March, June, September, and December. Annual institutional subscription rate (1992) is US $\$ 60.00$ in the United States and Canada; UK $\mathbf{f 3 7 . 0 0}$ elsewhere. Individuals may subscribe by becoming a member of the Economic History Association (see above). Prices include surface postage and insurance.

\section{Copyright $(\mathcal{C} 1992$ The Economic History Association}

All rights reserved. No part of this publication may be reproduced, in any form or by any means, electronic, photocopying, or otherwise, without permission in writing from Cambridge University Press. Photocopying information for users in the U.S.A.: The Item-Fee Code for the publication $(0022-0507 / 92 \$ 5.00+.00)$ indicates that copying for internal or personal use beyond that permitted by $\$$ ec. 107 or 108 of the U.S. Copyright Law is authorized for users duly registered with the Copyright Clearance Center (CCC) Transaction Reporting Service, provided that the appropriate remittance of $\$ 5.00$ per article is paid directly to CCC, 27 Congress Street, Salem, MA 01970. Specific written permission must be obtained for all other copying.

The Journal of Economic History (USPS 279-580) is published quarterly by Cambridge University Press. Second-class postage paid at New York, NY and additional mailing offices. Postmaster: Send address changes to The Journal of Economic History, Cambridge University Press, 110 Midland Avenue, Port Chester, NY 10573-9864. 


\section{THE JOURNAL \\ OF ECONOMIC HISTORY}

Volume 52

June 1992

Number 2

\section{PAPERS PRESENTED AT THE FIFTY-FIRST ANNUAL MEETING OF THE ECONOMIC HISTORY ASSOCIATION}

Lois Green Carr (Presidential Address)

Emigration and the Standard of Living: The Seventeenth Century

Chesapeake

Philip T. Hoffman, Gilles Postel-Vinay, and

JEAN-LAURENT Rosenthal

Private Credit Markets in Paris, 1690-1840

J. BRADFORD DE LONG

Productivity Growth and Machinery Investment: A Long-Run

Look, $1870-1980$

JOEL MOKYR

Technological Inertia in Economic History

JoHN C. Brown

Market Organization, Protection, and Vertical Integration:

German Cotton Textiles before 1914

Alfredo G. Esposto

Italian Industrialization and the Gerschenkronian "Great Spurt":

A Regional Analysis

FARLEy GRUBb

Educational Choice in the Era Before Free Public Schooling:

Evidence from German Immigrant Children in Pennsylvania, $1771-1817$

RAYMOND L. COHN

The Occupations of English Immigrants to the United States, 1836-1853

William H. Phillips

Patent Growth in the Old Dominion: The Impact of Railroad Integration before 1880

Alexander James Field

The Magnetic Telegraph, Price and Quantity Data, and the New Management of Capital

William A. SundSTROM

Last Hired, First Fired? Unemployment and Urban Black Workers During the Great Depression 
Sherrie A. Kossoudji ANd LAura J. Dresser

Working Class Rosies: Women Industrial Workers during World

War II

\section{SUMMARIES OF DOCTORAL DISSERTATIONS}

AnNe McCants

The Role of the Charitable Institution in the Early Modern Dutch

Economy: The Case of the Amsterdam Burgerweeshuis

Douglas J. Puffert

The Economics of Spatial Network Externalities and the Dynamics of Railway Gauge Standardization

Nathan Sussman

Mints and Debasements: Monetary Policy in France During the Second Phase of the Hundred Years' War: 1400-1425

Christopher Hanes

The Development of Nominal Wage Rigidity in Nineteenth-Century America

ShaWn EveretT Kantor

Property Rights and the Dynamics of Institutional Change: The Closing of the Georgia Open Range, 1870-1900

LAURA J. OWEN

The Decline of Turnover of Manufacturing Workers: Case Study Evidence from the $1920 \mathrm{~s}$

Discussion: Eugene N. White and Robert A. Margo 464

\section{EDITORS' NOTES}

\section{REVIEWS OF BOOKS}

\section{MEDIEVAL AND EARLY MODERN}

DAMERon. Episcopal Power and Florentine Society, 1000 1320

ARCHER. The Pursuit of Stability: Social Relations in Elizabethan London

DAvis. Shipbuilders of the Venetian Arsenal: Workers and Workplace in the Preindustrial City

Shammas. The Pre-Industrial Consumer in England and America

STARKEY. British Privateering Enterprise in the Eighteenth Century

\section{MODERN EUROPE}

ARISTIDE. La fortune de Sully

Palmer. Politics, Shipping and the Repeal of the Navigation Laws

E. N. White

SUTER. Schuldenzyklen in der Dritten Welt:

S. Ville 483

Kreditaufnahme, Zahlungskrisen und Schuldenregelungen

peripherer Länder im Weltsystem von 1820 bis 1986

C.-L. Holtfrerich 
Kingston-Mann and Mixter, Eds. Peasant Economy, Culture, and Politics of European Russia, 1800-1921

Frader. Peasants and Protest: Agricultural Workers, Politics, and Unions in the Aude, 1850-1914

RoSE, Ed. International Competition and Strategic Response in the Textile Industries Since 1870

Toniolo. An Economic History of Liberal Italy, 1850-1918

Patat and Lutfalla. A Monetary History of France in the Twentieth Century

J. R. Lehning 488

L. G. Sandberg 489

J. S. Cohen 490

E. N. White

\section{LATIN AMERICA}

SÁBATo. Agrarian Capitalism and the World Market:

Buenos Aires in the Pastoral Age, 1840-1890

Cortés Conde. Dinero, deuda y crisis: Evolución fiscal y monetaria en la Argentina, 1862-1890

MAXFIELD. Governing Capital: International Finance and Mexican Politics

Glade, Ed. Privatization of Public Enterprises in Latin America
A. J. Bauer
492
D. Felix
493

J. M. Cypher 495

M. de Paiva Abreu 496

\section{UNITED STATES}

Schulman. From Cotton Belt to Sunbelt: Federal Policy, Economic Development, and the Transformation of the South, 1938-1980

L. J. Alston 497

Boydston. Home and Work: Housework, Wages, and the Ideology of Labor in the Early Republic

KNIGHTs. Yankee Destinies: The Lives of Ordinary Nineteenth-Century Bostonians

STотт. Workers in the Metropolis: Class, Ethnicity, and Youth in Antebellum New York City

Cronon. Nature's Metropolis: Chicago and the Great West

SHEROW. Watering the Valley: Development along the High Plains and Arkansas River, 1870-1950

FLIGSTEIN. The Transformation of Corporate Control

Jeremy. Technology and Power in the Early American Cotton Industry: James Montgomery, the Second Edition of His "Cotton Manufacture" (1840) and the Justitia Controversy about Relative Power Costs

R. H. Bloch

499

S. M. Blumin 500

A. Bridges 501

L. P. Cain . 503

C. Coate 505

L. Galambos 506

M. Huberman 507

ADams. Damming the Colorado: The Rise of the Lower Colorado River Authority, 1933-1939

MANCALL. Valley of Opportunity: Economic Culture along the Upper Susquehanna, 1700-1800

CARR, Menard, and Walsh. Robert Cole's World: Agriculture and Society in Early Maryland

WERNER AND SMITH. Wall Street

BENSEL. Yankee Leviathan: The Origins of Central State Authority in America, 1859-1877

PRESTON AND HaInes. Fatal Years: Child Mortality in Late Nineteenth-Century America

Mullins. The Depression and the Urban West Coast, 1929-1933: Los Angeles, San Francisco, Seattle, and Portland
R. Lowitt 508
G. L. Main 509
P. C. Mancall 510
B. C. Nelson 512
P. Paludan 513

W. Lewchuk 514

P. Rhode 516 
NORRIs. Advertising and the Transformation of American Society, 1865-1920

V. Vinikas 517

Olney. Buy Now Pay Later: Advertising, Credit, and

Consumer Durables in the 1920's

R. Zevin 518

\section{ECONOMIC THOUGHT}

Alter. Carl Menger and the Origins of Austrian Economics

Parker and Stead. Profit and Enterprise: The Political Economy of Profit

P. J. Boettke 519

J. B. Davis 521

\section{GENERAL AND MISCELLANEOUS}

VESETH. Mountains of Debt: Crisis and Change in Renaissance Florence, Victorian Britain, and Postwar America

M. Edelstein 522

J. Mokyr 524

RothsCHILD. Bionomics: The Inevitability of Capitalism

Constantine, Ed. Letters of Eugene V. Debs

M. H. Nash 525

MCClosKey AND HeRsh. A Bibliography of Historical Economics to 1980

J. L. Rosenbloom 527

BERRY. Long-Wave Rhythms in Economic Development and Political Behavior

JEREMY, Ed. International Technology Transfer: Europe, Japan, and the USA, 1700-1914

J. C. Soper 528

M. Wilkins 529 